\title{
Executive coaching in diversity from the systems psychodynamic perspective
}

\author{
Authors: \\ Lerato Motsoaledi \\ Frans Cilliers ${ }^{1}$ \\ Affiliations: \\ ${ }^{1}$ Department of Industrial \\ and Organisational \\ Psychology, University of \\ South Africa, South Africa \\ Correspondence to: \\ Frans Cilliers \\ Email: \\ cillifvn@unisa.ac.za \\ Postal address: \\ PO Box 392, Unisa 0003, \\ South Africa \\ Dates: \\ Received: 31 May 2011 \\ Accepted: 24 Oct. 2011 \\ Published: 19 Mar. 2012 \\ How to cite this article: \\ Motsoaledi, L., \& Cilliers, F. \\ (2012). Executive coaching \\ in diversity from the \\ systems psychodynamic \\ perspective. SA Journal of \\ Industrial Psychology/SA \\ Tydskrif vir Bedryfsielkunde \\ 38(2), Art. \#988, 11 pages. \\ http://dx.doi.org/10.4102/ \\ sajip.v38i2.988
}

(C) 2012. The Authors. Licensee: AOSIS OpenJournals. This work is licensed under the Creative Commons Attribution License.
Orientation: The researcher applied role analysis from the systems psychodynamic perspective to executives in state departments to improve their awareness of the unconscious diversity dynamics that affect their roles.

Research purpose: The purpose of this research was to describe the application of systems psychodynamic role analysis and to determine its trustworthiness in assisting executives to work effectively with conscious and unconscious diversity dynamics in their organisations.

Motivation for the study: Executives generally struggle to understand the deeper meaning of diversity behaviour that manifests inside and around them, leading to conflict. Without understanding the unconscious meaning of the behaviour, organisations founder easily. Awareness of below-the-surface behaviour leads to insight and taking responsibility for diversity-related behaviours.

Research design, approach and method: The researcher coached six executives in South African state departments over a period of 10 months. The coaching addressed and analysed the executives' organisational roles. She analysed the data using discourse analysis.

Main findings: Themes relating to the diversity dynamics of gender, race, ethnicity, authority, disability, language, age, de-authorisation of diversity work and the coaching process emerged. The coaching assisted the executives to gain insights into below-the-surface diversity dynamics, to address diversity in a sustained manner and to take up their organisational roles more effectively.

Practical/managerial implications: Coached executives will have a more objective and dynamic experience of diversity issues that manifest in organisations, between colleagues and within themselves.

Contribution/value-add: Executive coaching from a systems psychodynamic perspective displays trustworthiness in improving participants' diversity awareness, especially with regard to gender, race, ethnicity and authorisation.

\section{Introduction}

Diversity has always been a salient feature of societies (Arredondo, 1996). However, attempts to deal with it have often been destructive and ineffective (Hilliard, 2001/2002). Relations between diverse cultures are fraught with paranoia, hatred and envy (Cytrynbaum \& Noumair, 2004). This leads to diverse workplaces that poor communication between identity groups, poor teamwork and low productivity characterises (Thomas, 2002). Consequently, the effects of segregation and intolerance remain visible in many segments of society (Dixon \& Durrheim, 2003) and in the workplace (Cavaleros, Van Vuuren \& Visser, 2002).

Research into workplace diversity has escalated over the last few years (Cañas \& Sondak, 2010; Robinson, 2009). It has become part of organisational development inputs in large organisations worldwide (Kirton \& Greene, 2010). They focus on multiculturalism (Fleras, 2009), cultural intelligence (Livermore, 2009) and cross-cultural diversity (Human, 2005). Research also reports on the effect of diversity awareness on work performance (Hopkins, 2009), leadership (Hannum, McFeeters \& Booysen, 2010), strategy and equal opportunities (Dobbin, 2009). We generally accept that diversity issues represent some of the most complex dynamics in the modern organisation and that the awareness of these improves workplace performance and relationships (Cañas \& Sondak, 2010).

The democratisation of South African workplaces (Van Jaarsveld \& Van Eck, 2002) because of the changing socio-political landscape (Cavaleros et al., 2002), started redressing processes 
(Van Jaarsveld \& Van Eck, 2002) that elevated the diversity agenda (Fraser-Moleketi, 2001; Human, 2005). Various pieces of legislation, that the Constitution of the Republic of South Africa (South African Department of Labour, 2004) underpins, have played a pivotal role in this democratisation, with the Employment Equity Act (South African Department of Labour, 2004) driving workplace representivity (Meyer \& Boninelli, 2004; Human, 2005).

Although there has been significant progress in changing the demographics of workplaces (Cavaleros et al., 2002), there are still challenges. The ninth and latest report that the Commission for Employment Equity submitted for the year 2009 revealed gross under-representation of Africans (Black people), Coloured people and people with disabilities in key areas of the labour market (Commission for Employment Equity Annual Report, 2009).

South Africans of Chinese descent, classified as Coloured people in apartheid South Africa and declared a designated group in 2008, did not feature in the report (Mbola, 2008). Apartheid (Meyer \& Boninelli, 2004) was responsible for the concentration of the White group in key areas of the labour market. In addition, resistance to transformation (Booysen, 2007; Fraser-Moleketi, 2001; Human, 2005) has reinforced the status quo. This has caused a misalignment between equity legislation and formal organisational policies on the one hand and their implementation on the other (Booysen, 2007).

South African organisations are aware of this situation and attempt to democratise the workplace through diversity management programmes (Booysen, 2007) that focus on group interventions. Many of these programmes are mechanistic in nature (Cavaleros et al., 2002) and few address diversity from an organisational dynamic stance. One example is the Robben Island Diversity Experience (Cilliers \& May, 2002; Pretorius, 2003). Fewer organisations are using individual inputs, like individual coaching, to improve diversity awareness. The researcher could trace no relevant international or South African research on diversity coaching with which to compare the present research.The purpose of this research was to describe the application of systems psychodynamic role analysis and to determine its trustworthiness in assisting executives to work effectively with conscious and unconscious diversity dynamics in their organisations. This research shifted systems psychodynamics from its traditional group orientation to the individual context of executive coaching (Brunning, 2006; French \& Vince, 1999; Huffington, Armstrong, Halton, Hoyle, \& Pooley, 2004; Kets de Vries, 2004; Kilburg, 2000; Newton, Long \& Sievers, 2006). The systems psychodynamic approach to diversity draws attention to below-the-surface diversity dynamics that the field of diversity management often ignores (Cilliers \& Koortzen, 2000). Diversity dynamics develops the capacity of executives to understand intrapsychic, interpersonal and systemic issues (Brunning, 2006; Kets de Vries \& Korotov, 2007). Therefore, executives should address diversity challenges more effectively.
The literature suggests that effective diversity management is a business strategy geared to increase organisational competitiveness (Meyer \& Boninelli, 2004). However, diversity management typically resembles ad hoc training (Cavaleros et al., 2002). It fails to institutionalise the learning and to sustain transformation (Armstrong \& Huffington, 2004) because it does not address hidden and unconscious diversity forces (Cilliers \& May, 2002).

Organisational leaders should lead diversity initiatives to facilitate successful change (Hyter \& Turnock, 2005). Understanding the role of unconscious dynamics in making decisions, leadership and organisational effectiveness is also fundamental to leadership (French \& Vince, 1999; Kilburg, 2004). Examples are how leaders often deny and repress emotionally threatening diversity issues and attribute conflict to them (Cilliers, 2007).

Executive coaching offers a viable solution to the criticism that the field of diversity management lacks an innovative approach to its challenges. Dreachslin (2007) acknowledged the effectiveness of executive coaching in raising the diversitysensitivity orientation of leaders. Kilburg and Diedrich (2007) lauded the effectiveness of psychodynamic executive coaching in improving learning. According to Newton et al. (2006), leaders ought to appreciate the roles of their intrapsychic environments, role factors and organisational dynamics in order to take up their roles effectively.

\section{Diversity}

There is much confusion about the conceptualisation and definition of diversity, particularly about the narrowing or broadening of its boundary (Booysen, 2007). It is a fluid and dynamic concept (Cañas \& Sondak, 2008), so most diversity definitions emphasise its all-encompassing nature (Thomas, 2005). There are similar challenges about its key concepts of race (Schiffrin, Tannen \& Hamilton, 2001), gender (Syed \& Murray, 2008; Thorne, 2001), culture (Cox, 2004) and disability. Motsoaledi (2009) gave a full interpretation of these concepts in the context of coaching.

Social dominance theory incorporates many theories of oppression to explain sources of group-based prejudice and discrimination (Aquino, Stewart \& Reed, 2005). The theory presupposes that inequality is inevitable. Its main tenet is that group-based social hierarchies are the fundamental structures of all human societies. One or a few dominant groups own a disproportionately large share of positive social value or material things. Conversely, subordinate groups have a disproportionately large share of negatives (Sidanius \& Pratto, 1999).

Realistic group conflict theory posits that intergroup conflict is the result of real groups competing over real material or symbolic resources in a winner-takes-all manner that breeds hostility (Brief, Umphress, Dietz, Burrows, Butz \& Scholten, 2005). The neoclassical elite approach focuses on conflict between the ruling elites and the masses of ordinary people. 
The ruling elite rationalise their power through systems that legitimise their ideologies as sacrosanct (Sidanius \& Pratto, 1999).

Social identity theory focuses on aspects of a person's self-concept that has group membership (Tajfel 1981) as its basis. It leads to the development of gender, racial and cultural identity through socialisation and internalisation (Korostelina, 2007). Identifying with members of the ingroup elicits a similarity bias, a typical outcome of which is favouritism and interpersonal attraction towards demographically similar individuals. The similarityattraction paradigm demonstrates how people relate to one another because of their social identities. They form cliques around identity membership. Therefore, demographically similar organisational members enjoy important benefits, like supportive supervision (Foley, Linnehan, Greenhaus \& Weer, 2006).

Ayoko and Härtel (2006) coined the term 'diversity leadership' to refer to those who lead or manage diverse workgroups in order to bring about inclusive workplaces. A diversity leadership challenge is the paucity of leadership practices that respond appropriately to diversity problems (Aguirre, 2008). Another challenge is workplace bullying (Lutgen-Sandrik \& Alberts, 2006), which can occur because of gender or race (Lutgen-Sandrik \& Alberts, 2006). Because competition, power struggles, envy and prejudice characterise diverse workplaces, they can trigger bullying (Heames \& Harvey, 2006). A recurring diversity leadership challenge is its overt and covert resistance to diversity initiatives (Hebl, Madera \& King, 2008). Covert resistance can take the form of unconscious collusive dynamics, when employees harbour an unconscious rational-irrational conflict in which overt support for equity initiatives exists alongside its covert denigration (Cilliers \& Stone, 2005).

Communicating a contextualised diversity business case is the imperative of diversity leaders (Hyter \& Turnock, 2005). In doing so, they facilitate an awareness of how diversity issues manifest in their specific organisations to ensure that the mixed results of scientific research on the business case for diversity does not confuse their organisations' systems (Cañas \& Sondak, 2010).

\section{Systems psychodynamics}

Systems psychodynamics refers to the repertoire of psychological behaviours within and between groups and organisations as well as their related conscious and unconscious motivating forces. It encompasses the triad of psychoanalysis, group dynamics and systems theory (Armstrong, 2005). Applying psychoanalytic phenomena to work and organisations facilitates a deeper understanding of the unconscious in organisations (Townley, 2008), oedipal struggles (Czander, 1993) and social defences (Lyth, 1989).

Object relations theory provides an interpersonal perspective on psychoanalysis (Townley, 2008) and acknowledges that, from birth, people have relationships, most significantly with their mothers (Klein, 1997). It highlights primitive defence mechanisms like splitting, introjections, projection and projective identification against anxiety (Stapley, 2006). It requires an object to identify with, introject and contain projections as if they belong to the object (Klein, 1997).

Paranoid and persecutory anxiety is prevalent in the paranoid-schizoid position, in which splitting into good and bad characterises the ego state (Klein, 1997). This position emerges when organisations polarise into all-good and allbad parts (Diamond, Allcorn \& Stein, 2004). The depressive position occurs when people integrate the good and bad parts of the object and allow reparations to restore and protect the injured objects (Klein, 1997). Organisationally, the depressive position triggers empathic interactions, uses less regressive defences (Diamond et al., 2004) and protects against destructive impulses (Huffington et al., 2004).

Systems theory studies organisations and their management in a manner that allows for an analysis and synthesis of relatedness and interactions in complex and dynamic environments (Armstrong, 2005). When one applies the theory to groups, (like when the executive becomes a team leader), two emotional states characterise behaviour. These are the work group and the basic assumption group (Stapley, 2006). The work group is sophisticated, based in reality and actively pursues task achievement (Cytrynbaum \& Noumair, 2004). When anxiety-provoking tasks confront it, it regresses unconsciously to a basic assumption group. This moves away from task accomplishment to five different positions (Bion, 1961; Hayden \& Molenkamp, 2004; Turquet, 1974). These are:

- in dependency, it seeks a powerful leader to satisfy its needs

- in pairing, it focuses on fusing in the hope that a leader will emerge

- in fight-flight, it tries to fight an enemy or flee from a threat

- in oneness, it seeks to form a powerful union to achieve wholeness

- in me-ness, it behaves as if it is a non-group to promote individuality.

Valence is the propensity, vulnerability or readiness to combine and collude with others in acting upon basic assumptions (Huffington et al., 2004).

\section{Executive coaching}

Kilburg and Diedrich (2007) defined executive coaching as formal, collaborative relationships between clients and consultants. Consultants help their clients to improve their work performance and personal satisfaction and thereby to improve organisational effectiveness.

Despite its proliferation since the 1990s, (Kilburg, 2004), the field lacks universally recognised standards of expertise and empirical research on its praxis in management consultancy (Kilburg \& Diedrich, 2007). The results of executive coaching have been brilliant, effective, bad or mixed (Brunning, 2006). 
Harmful results are ascribed to executive coaches lacking rigorous psychological training. Lee (2010) lauded the psychodynamic approach to coaching because of its capacity to work below the surface and to manage boundaries, but cautioned that its depth was not always appropriate to shortterm, pragmatic engagements.

In response to the prevailing tendency of focusing on the mechanics of coaching whilst ignoring the complexities of the coaching process, Kilburg (2004) incorporated complexity theory, human behaviour, psychodynamics and pragmatism with executive coaching. Similarly, Kets de Vries and Korotov (2007) highlighted leadership dynamics, collusive dynamics, social defences, corporate culture, toxic organisations and imprisonment of the past as key aspects that coaching should address.

\section{Organisational role analysis}

Newton et al. (2006) and Brunning (2006) applied Organisational Role Analysis (ORA) to in-depth coaching. ORA is a method of working with people to enable them to fulfil their roles effectively (Brunning, 2006). Newton et al. (2006) stated that the gender, training and age of a client can affect the experience of a role and fulfilling that role. ORA investigates the role that systemic issues play in creating work and role performance problems for executives (Newton et al., 2006). ORA does not focus on solving problems because leaders tend to focus on solving problems for which they already have solutions (Newton et al., 2006). Instead, it focuses on the iterative processes of hypothesising and testing hypotheses in the work environment.

An important task of coaches is to provide safe (Lee, 2010) and holding (Winnicott, 1965) environments to facilitate reflective containment (Diamond, 2007; Kilburg, 2000). Key aspects of containment include a formal agreement, boundary conditions, information exchanges (Diamond, 2007), deep listening, reliability and openness (Huffington et al., 2004). As a behavioural process, projective identification provides containment when coaches accept the clients' projections and holds them until they are ready to explore them (Huffington et al., 2004). Empathy requires coaches to be in the depressive position when they do inner reparative work (Brunning, 2006). It is a key trait of systems psychodynamic coaches. Coaches assist clients to have empathy for themselves in role to enable them to confront their flaws and unpleasant aspects of their role experiences and to trade psychotic for reality thinking (Newton et al., 2006).

The researcher formulated the research problem using this background. The problem is how one should coach executives from a systems psychodynamic perspective to enable them to understand conscious and unconscious diversity dynamics so that they can take appropriate actions on behalf of their organisations.
The research intended to achieve five objectives. They were to:

- explore the conscious and unconscious diversity dynamics that executives experience in their workplaces

- explore the intra-psychic environment of executives and its interplay with diversity dynamics

- deepen the insights of executives into the conscious and unconscious diversity dynamics to assist them to work more effectively with diversity and to enable them to take action on behalf of their organisations

- contribute to the theoretical knowledge about coaching executives on the subject of diversity from a systems psychodynamic perspective

- determine the trustworthiness of executive coaching from a systems psychodynamic perspective.

This research is relevant to contemporary organisations, particularly in South Africa, because it addresses unyielding diversity issues because of their complex and deep-rooted nature. The extended duration of executive coaching deepens understanding and addresses diversity issues meaningfully. The researcher could trace no research that reported on executive coaching in the area of diversity from a systems psychodynamic stance, including ORA. Therefore, this research is the first in the field.

The structure of rest of the article follows. The researcher presents the research design, particularly the research approach and strategy. The research method follows. It consists of the setting, the roles of the researcher, the sampling method, data collection, recording and analysis. The researcher then mentions the strategies she used to ensure quality data. Thereafter, she presents the findings as manifested themes with references that link the findings to supportive literature. The discussion contains the research hypothesis. The conclusion, recommendations, limitations and suggestions for further research conclude the article.

\section{Research design Research approach}

The researcher used qualitative research (Terre Blanche, Durrheim \& Painter, 2006) to understand the phenomena in context-specific settings (Golafshani, 2003) and to make sense of, or interpret, the phenomena according to the meanings participants attach to them in line with the constructivist epistemological approach (Klenke, 2008).

The research was descriptive. It focused on the participants' cognitive, affective and symbolic actions and the meanings associated with observable behaviours (Myers, 2000). The comprehensive and systematic examination of phenomena provided rich, in-depth (Le Roux, 2003) and contextual knowledge (Yin, 2003).

\section{Research strategy}

According to Cox (2004), the case study method is crucial when one studies diversity-related topics that tend to lack 
well-established theoretical bases. Therefore, the researcher used several case studies (Terre Blanche et al., 2006) to investigate empirically the phenomenon of learning during coaching in a real-life context (see Myers, 2000). This allowed for an in-depth examination of the behaviours that emerged from several sources of information (Denzin \& Lincoln, 1994).

The researcher regarded this strategy as appropriate because time and place delimited the system. The case study was intrinsic (to obtain a better understanding of behaviour to serve the interest of the specific department) and instrumental (to give feedback to managers on the coaching themes that emerged [see Denzin \& Lincoln, 1994])

\section{Research method}

\section{Research setting}

The researcher conducted the research in three state departments. She kept the names of the departments confidential for publication as all parties agreed to do during contracting.

\section{Entrée and establishing researcher roles}

The first researchers had three distinct roles. The first was as consultant or coach (Lowman, 2002) to the different state departments. The three departments assigned a departmental coordinator, with whom she negotiated the practicalities, for the coaching project. Her second role was as participant observer (Brewerton \& Millward, 2004) to witness, describe, record and make sense of the coaching whilst being part of it at the same time (Clarke \& Hoggett, 2009). Her third role was that of discourse researcher (Cilliers \& Smit, 2006) to analyse the data. The second researcher was the supervisor (see Clarke \& Hoggett, 2009).

Both researchers used the self as the instrument of analysis (McCormick \& White, 2000). Both are psychologists with doctorate degrees. They have specific training, theoretical knowledge as well as experience in systems psychodynamic consulting and research that conforms to the requirements that Brunner, Nutkevitch and Sher (2006) set.

\section{Sampling}

The researcher used purposive sampling. This allowed her to select participants who would contribute best towards an indepth and rich understanding of their coaching experiences (Klenke, 2008). She chose six executives in different departments. Two were Black men, two were White women, one was a Black woman and one was a Coloured man.

\section{Data collection methods}

The researcher used Organisational Role Analysis (Newton et al., 2006) to collect data. She followed four main steps. Firstly, she explained the ORA model of role and its central concepts. Secondly, the participants drew role-ogrammes and role biographies through which they explored their experiences of role, task, role relatedness and relationships (Newton et al. 2006). Thirdly, the researcher drew associations with the drawings. Finally, she explored the extent to which the person, the role and organisation's interrelatedness uncovered fundamental role issues (Newton et al., 2006; Sievers, 2009).

The researcher coached the participants over a period of 10 months. The first two coaching sessions were semi-structured and focused on assessing participant-in-role experiences. In the third session, the researcher assessed significant unresolved diversity issues that confronted the participants. Here the participants had role responsibilities, the outcomes of which were important to them. Subsequent sessions focused primarily on the participants' preoccupations with pressing and emerging issues. The middle sessions evaluated the coaching progress, shifts or areas where the participants felt stuck. The last session focused on termination issues, feedback to parties and on future reflections.

\section{Recording of data}

In her role as coach, the first researcher took meticulous notes during and after each coaching session to ensure that she captured fully the conscious, the logical, the unconscious and the irrational aspects of the coaching experience (see Van Manen, 1990). She then typed the data and stored them safely.

\section{Data analysis}

The researcher used systems psycho-dynamically informed discourse analysis (Schiffrin et al., 2001). This offered a critical perspective. It also focused on social and political issues, the context within which interactions and communications occur (Schiffrin et al., 2001), the lived experiences and the economic factors that influence them (Henning, 2004). It allowed for understanding deep, covert and complex organisational behaviour (Cilliers, 2007; Smit \& Cilliers, 2006).

The method determined the discourses that framed the language action and interpretations of the participants as well as how their social contexts generated and maintained their discourses (Schiffrin et al., 2001). The researcher read the raw data several times to identify more compelling themes, uncover deeper meanings to allow for adequate interpretations from the systems psychodynamic perspective and to provide theoretical support.

\section{Strategies employed to ensure quality data}

The researcher ensured trustworthiness through credibility, dependability, transferability and confirmability (Healy \& Perry, 2000). She ensured credibility by using several sources of information (Devers, 1999) and increased its truth-value (Dyson \& Brown, 2006) through collaborative hypothesising (Newton et al., 2006). She fully explicated the theoretical stance, the research method as well as the process and logic underlying the research to promote dependability (Evans, 2007). Reporting on the contexts within which the research occurred and their salient features ensured transferability (Dyson \& Brown, 2006). She improved confirmability (Golafshani, 2003) through her extensive experience in the systems psychodynamic tradition and in diversity. Therefore, 
she used self-knowledge, self-reflection, and awareness of depth psychological processes like counter-transference and projective identification.

The researchers ensured rigour through the first researcher's request to the organisation for permission to conduct the research project in a written proposal. This outlined the purpose, context and process as well as the recruitment criteria for participants. Ethical considerations centred on issues of privacy, confidentiality and transparency about using the data, as Rowley (2004) advocated. Trust, respect, mutual consent and signed contracts were important for ensuring ethical engagements between the researcher and the participants (Diamond, 2007).

\section{Findings}

The executives' conscious and unconscious diversity dynamics emerged in six themes. The most noticeable were gender and race. Ethnicity and culture; power and authority; disability, language and age; and the de-authorisation of diversity work by executives were less significant.

\section{Gender diversity dynamics}

The women leaders discarded their femininity to deal with their anxieties of engaging with traditionally masculine leadership roles (Cheng, 1999). Projecting masculinity into leadership roles seemed to pressure the women leaders into trading typically feminine attributes like caring, tenderness and emotional sensitivity (Syed \& Murray, 2008) for aloofness and aggression. In doing so, they attracted aggression (Stapley, 2006) and envious reactions (Klein, 1997) from the men. This appeared as resistance to female leadership, projecting inadequacy onto the women leaders and using aggression to dominate and de-authorise them. The women leaders unconsciously colluded in their de-authorisation by identifying with projections of 'good enough' mothering (Stapley, 2006). When this projective identification (Klein, 1997) occurred, the women leaders discarded their destructive impulses and took up the nurturing role. This fostered dependency in their subordinates (Sievers, 2009). This made it difficult for the women leaders to confront conflict.

Shifting power relations between the Black men and the Black woman evoked catastrophic anxiety (Huffington et al., 2004) in the Black men. It emerged as resistance to pairing with the Black woman in new ways that could reveal their vulnerabilities. Confusion emerged in the Black woman leader. Cultural demands stifled her as she transcended her traditional position of subservience. This created several challenges for her.

\section{Race diversity dynamics}

The departments used Black executives as containers of incompetence, for which they have a valence (Huffington et al., 2004) because of their history of deprivation, exclusion from meaningful work roles and an inferior education system
(Booysen, 2007). White executives still yielded significant power in the workplace and in structures of transformation (Meyer \& Boninelli, 2004).

This fundamental lack of change perpetuated the inferioritysuperiority dynamic that colours racial interactions. The Black executives acted out passive-aggression in these interactions instead of confronting White executives about the denigration they experienced at their hands (Peltier, 2001). The prolonged subjugation of Black people and their introjection of inferiority triggered anxieties about their individuation and empowerment. Their idealisation of White executives fuelled it and it manifested as their infantilisation (Blackman, 2004). The long road to true economic empowerment for Black people triggered fight-flight reactions because the Black people resented the continued accumulation of wealth of White people and because the Black people continued to labour for them. The younger generation of Black people also directed this resentment unconsciously at the older Black generations to which they were indebted for the sacrifices the older generations had made for them.

White executives resisted the redistribution of power and resources and experienced the loss of long-held positions of power and privilege as unfair dispossession. This triggered rage-induced implosions, explosions and envious attacks on the Black executives (Laubscher, 2001). These manifested as complaints. The Black executives engaged with their newly acquired privileges in an ambivalent way. This seemed to stem from anxieties about perceptions of being persecutors, as if privilege and persecution had become synonymous. The departments used White executives as containers of persecution anxieties and workplace uncertainties. They used White men, in particular, as containers of resistance to transformation because of their valence for this. The White executives experienced predominantly Black organisations, which bullied and victimised them, as traumatic (Branch, Ramsay \& Barker, 2007).

Black and White executives used the Coloured executive to contain anxieties of ambiguity (Jung, 2000) and for experiments with newness as well as inter-racial interactions. The Coloured executive also experienced deprivation as he battled to find his place in the workplace (Pretorius, 2003). Racial pairing created safety for members of the in-group and maximised their access to resources at the expense of the out-group, whilst entrenching the separation of the races. The challenges of power sharing and anxieties of engulfment made racial pairing difficult because it was either transient or disrupted.

The departments defended themselves against the primal anxieties that race evoked (Freud, 1948) and therefore denied open and honest race discourse. The notion of a rainbow nation seemed to be a defence against working through diversity challenges and moved to the depressive position. The Black executives defended themselves against racial anger largely through rationalisation, sublimation, 
suppression and humour (Blackman, 2004; Peltier, 2001; Townley, 2008). However, the disowned racial anger slipped through in a free-floating manner.

The White executives defended themselves against racial discomfort largely through denial, sublimation, rewriting the racial script (Stapley, 2006; Townley, 2008) and splitting the past from racial discourse (Pretorius, 2003). Apartheid experiences have been traumatic for Black people and residues of racism trigger flashbacks and traumatic memories. This has heightened their sensitivity to issues of race and highlighted their need for catharsis, which the departments denied them by silencing them and labelling them negatively when discussing racial issues. This resulted in difficulties with healing race-related trauma and perpetuated race conflicts. The races struggled to find a mutually safe place from which they could address race baggage effectively (Pretorius, 2003). Therefore, this reinforced the strong tendency to remain in the paranoid-schizoid position (Klein, 1957). In general, the races were fixated on fight-flight and colluded to entrench racial separation (Cytrynbaum \& Noumair, 2004).

\section{Ethnicity and culture diversity dynamics}

Ethnic affiliation fostered support, increased access to resources as well as networks of power and positively influenced career advancement for members of the in-group. Satisfying the need for affiliation and advancing one's social identity group (Sidanius \& Pratto, 1999) seemed to be more important than pragmatism and fairness. The Black executives who belonged to the ethnic groups of political leaders seemed to enjoy the benefits of empowerment the most.

Through the cultural estrangement born of oppression (Sonn \& Fisher, 2003), the Black executives colluded in denigrating Black culture and idealising western culture. This resulted in their assimilation into White culture (Sue, 2006). Whilst the Black executives used racial homogeneity to defend themselves against ethnic conflicts within the Black groups, the White executives used cultural diversity to defend themselves against conflicts between race groups.

\section{Power and authority diversity dynamics}

The need for affiliation, survival and domination meant that those in powerful positions surrounded themselves with members of their in-group. Those with the power to favour their in-group members then disproportionately allocated resources at the expense of the members of the out-group (Sidanius \& Pratto, 1999). Authority figures escaped their incompetence by projecting them on to subordinates whilst denying anxiety-provoking changes that threatened the status quo and their survival (see Hirchhorn, 1997).

In turn, these authority figures received projections of persecution and narcissism (Kets de Vries, 2004). The authority figures triggered unconscious conflicts in subordinates. They resulted in dependence, counter-dependence and envyrelated fantasies of merging with them (Stapley, 2006). When authority figures limited the powers of subordinates, they evoked anxieties of the oedipal type (Czander, 1993).

\section{Disability, language and age diversity dynamics}

The departments used the disabled executives as containers of deficiencies because of their valence for this, their overt handicaps and ingrained beliefs about their incapacity (Black \& Stone, 2005). Poor access to basic needs, like food, because of structural obstacles seemed to reflect an unconscious desire to keep the disabled dependent and vulnerable and to wish them away.

The departments used older executives as containers of irrelevance (Field \& Jette, 2007) and younger executives as containers of hope. Older executives paired with younger ones in the hope of giving birth to the desired, idealised order (Cytrynbaum \& Noumair, 2004). The departments also used the older executives to do the work of the superego for their organisations. Parental objects evoked oedipal anxieties when younger executives with authority had to confront them about their performance problems (Cytrynbaum \& Noumair, 2004).

The departments used English as a tool of power and to denigrate those who could not use the language proficiently (Simpson, 2008). The Afrikaner-speaking executives displaced their aggression about the replacement of Afrikaans by English to Black people, instead of directing it at the Englishspeakers, who own the language, perhaps because they saw Black people as easy targets that were unlikely to retaliate (Stapley, 2006).

\section{Executives and diversity}

The workplace was often a potent arena for triggering the unresolved intrapsychic conflicts of executives (Kets de Vries \& Korotov, 2007). Through transferential processes and primitive defences, executives re-enacted their unresolved conflicts with colleagues, subordinates and authority figures that represented significant objects, sometimes from childhood. At times, deep rooted and irrational motives that stemmed from childhood influenced the executives' diversity experiences and interactions.

These motives caused the executives to get stuck without realising it. However, they could consciously work through the insights to motivate changes. The executives were able to authorise themselves in their roles and take constructive action for their teams and their organisations. Some of the actions they took included:

- authorising the self-in-role fully

- confronting unpleasant and transforming aspects of the self-in-role

- confronting previously avoided conflict

- espousing a collaborative attitude to foster healthy team interactions

- working actively to achieve racial collaboration

- bringing up difficult and previously suppressed conversations. 


\section{Discussion}

The purpose of this research was to describe the application of systems psychodynamic role analysis in assisting executives to work effectively with conscious and unconscious diversity dynamics in their organisations and to determine its trustworthiness.

The research was important for addressing diversity challenges in the context of transforming South African organisations. Coaching executives from the systems psychodynamic perspective offered a new way of working with diversity in order to improve the existing methods of addressing diversity challenges. Prolonged engagement with executives on diversity was essential because leaders have to drive successful change in organisations. This research was the first attempt to publish findings about diversity coaching experiences using systems psychodynamics in an organisational setting and in a racially complex environment like that of South Africa. Therefore, it links with, and adds to, the existing research on the manifestation of diversity elements in psychotherapy (Foster, Dickinson, Bishop \& Klein, 2006) as well as to the research on cultural differences, racism and racial dynamics as phenomena and their influence on leadership, authority and power (McRae \& Short, 2010; White, 2006).

Themes of key diversity dimensions emerged in this research. The gender theme uncovered dynamics that unfolded when women engaged with the traditionally masculine role of leadership (Syed \& Murray, 2008). The race theme revealed splits that made pairing across races difficult and challenges of finding mutually safe places from which race groups could address their racial baggage effectively (Pretorius, 2003). Ethnic affiliations conferred material and symbolic privileges upon members of similar identity groups. Similarly, those in powerful positions surrounded themselves with members of their in-group to bolster their support and keep the power within their identity groups (Sidanius \& Pratto, 1999). The disabled and old functioned as containers of deficiencies and irrelevance respectively, whilst the departments used English to denigrate those less proficient in the language (Black \& Stone, 2005; Field \& Jette, 2007; Simpson, 2008).

This research showed that executive coaching in diversity from the systems psychodynamic perspective displays trustworthiness (Clarke \& Hoggett, 2009). During the early stage of coaching, the executives adopted a simplistic and superficial understanding of diversity, associated with denials of diversity challenges, illusions of harmony and flights into sameness.

This is consistent with the findings that Cilliers and Terblanche (2010) reported. The continuous nature of the coaching ensured that the participants did not abandon pertinent issues easily (Kilburg \& Diedrich, 2007). The collaborative nature of the organisational role analysis approach, with its emphasis on generating hypotheses (Newton et al., 2006) stimulated interest and curiosity in uncovering deeper layers of meaning (Brunning, 2006). Within the reflective and contained space that the coaching provided (Diamond, 2007; Kilburg, 2004), the executives were more willing to process their learning about intrapsychic, interpersonal and systemic factors, transferential and counter-transferential processes, defence mechanisms and using the self as an instrument. They were also more willing to shift from the paranoidschizoid position to the depressive one (Klein, 1997) and to take risks on behalf of their organisations.

To explore the notion of trustworthiness further, the researcher measured the findings against the criteria for organisational learning according to the systems psychodynamic perspective (Bain, 1998; Campbell \& Huffington, 2008; French \& Vince, 1999).

\section{Reflection space and containment}

The coaching sessions served as a space for reflection where the executives became learners about their psychodynamic primary tasks as executives. During this, the coach contained the executives' anxieties and their defences. Therefore, they could explore previously unaware possibilities with eagerness, curiosity and intensity. At the end of the coaching contract, the executives showed 'executive wisdom' (Kilburg, 2004). This is taking up the leadership role openly to experience and explore own, team and organisational behaviours creatively to achieve cognitive understanding, a strong sense of self and a systemic awareness of process and dynamics.

\section{The evolution of the organisational container and the contained}

The executives developed their container management competence (Bion, 1961). This was evident in their insight into their systemic defences that manifest in management as well as their own defensive leadership behaviour.

\section{Interdependence}

The executives showed strong evidence of interdependence (Stapley, 2006) as they moved away from dependence and non-ownership. Towards the end of the coaching, their experiences seemed less fragmented and more inclusive of the systemic primary task.

\section{Exploration of the dynamic primary task}

The executives started to differentiate between their primary task, off-task and anti-task behaviour to their departments. This included what is relevant and appropriately complex (those aspects of the leadership that are congruent to their primary tasks) and what is irrelevantly simplistic (those aspects that made them defend against anxiety, like using fight and flight responses). They learned to regulate themselves (Campbell, 2007) and to respond to the rational aspects of their primary tasks with insight, understanding and to manage relationships more effectively. 


\section{Boundary management}

The executives' awareness about the dynamic meaning of personal, interpersonal and organisational boundaries facilitated their competence to take up their leadership roles more consciously (Brunning, 2006).

\section{Taking up the leadership role with authority}

The executives learned the cognitive meaning of leadership and its appropriate levels of authorisation (Kets de Vries, 2004). The experiential nature of the coaching facilitated the enlargement of their leadership behavioural repertoire. This was evident in how they could differentiate between rational and irrational leadership behaviour.

\section{Conclusions and recommendations}

The hypothesis the researcher formulated was that executive coaching, from the systems psychodynamic perspective, shows trustworthiness in its capacity to uncover diversity dynamics about gender and race, ethnicity, authority, disability, language, age and de-authorisation, and that the coaching process assists executives to understand their own, their colleagues' and their organisations' conscious and unconscious diversity dynamics.

The conclusion the researcher reached in this descriptive research was that executive coaching in diversity, from a systems psychodynamic perspective, shows trustworthiness. It is able to uncover intrapsychic, systemic and below-thesurface diversity dynamics in order to assist executives to work more effectively with diversity.

The researcher recommended that executives in state departments should be allowed regular opportunities to increase their awareness of their own diversity representations (especially their objects of race and gender) through individual coaching from, and small group discussions with, psycho-dynamically informed psychologists.

They should also be encouraged to bring their awareness of diversity to their departmental meetings and to assist their colleagues to observe 'things diverse' in natural settings in order to deepen general insights towards improving their leadership. This will become a type of public discourse around diversity in order to manage diversity in responsible and dynamically informed ways. On a broader scale, the executives could meet regularly as a group to process their experiences and identify opportunities that they can use to improve diversity management in the organisation (Kashlak, Phatak \& Bhagat, 2009).

The researcher recommended that the focus of managing diversity should start with individual executives, move towards their immediate teams, then to the organisation in order to develop a congruent product for managing workforce diversity (Mujtaba, 2009; Schaepkens, 2010).

\section{Limitations of the study}

The researcher identified a number of limitations. There is a paucity of literature on systems psychodynamics in the South African diversity context and on coaching from a systems psychodynamic perspective. Organisational role analysis has acknowledged its neglect of diversity, particularly because non-traditional role players currently hold senior leadership positions (Newton et al., 2006).

In this research, the primary mandate of the participants was not to manage diversity explicitly, although they did manage executives with different diversity challenges. The participating organisations supported diversity mostly through equity-driven legislation and policies. Therefore, they did not engage with diversity fully. This prevented the participants from stretching themselves fully when they took action based on their learning during coaching. The research also excluded certain groups like White men, Indian people and Coloured women.

The researcher recommended that future research should focus on exploring executive coaching from a systems psychodynamic perspective further, thus expanding the literature. Apart from the diversity dimensions the researcher included in this study, future research should also focus on ethnicity, disability, age, language and sexual orientation. It should include all South Africa's diverse groups (especially White men, Indian people and Coloured women).

\section{Acknowledgements Competing interests}

The authors declare that they have no financial or personal relationship(s) that may have inappropriately influenced them when writing this paper.

\section{Authors' contributions}

L.M. (UNISA) conducted the literature review and empirical study. F.C. (UNISA) was the research supervisor and helped with the academic editing of the work.

\section{References}

Aguirre, A. (2008). Diversity, social capital, and leadership practices: Building inclusive learning organisations. International Journal of Management and Decision Making, 9(5), 526-542. http://dx.doi.org/10.1504/IJMDM.2008.019785

Aquino, K., Stewart, M.M., \& Reed, A. (2005). How social dominance orientation and job status influence perceptions of African American Affirmative Action beneficiaries. Personnel Psychology, 58(3), 703-745. http://dx.doi.org/10.1111/ j.1744-6570.2005.681.x

Armstrong, D. (2005). Organisation in the mind: Psychoanalysis, group relations and organisational consultancy. London: Karnac Books.

Arredondo, P.M. (1996). Successful diversity management initiatives: A blueprint for planning and implementation. London: Sage.

Ayoko, O., \& Härtel, C. (2006). Cultural diversity and leadership: A conceptual model of leader intervention in conflict events in culturally heterogeneous workgroups. Cross Cultural Management, 13(4), 345-360. http://dx.doi. org/10.1108/13527600610713431

Bain, A. (1998). Social defences against organisational learning. Human Relations, 51(3), 413-429. http://dx.doi.org/10.1023/A:1016952722628

Bion, W.R. (1961). Experiences in groups and other papers. London: Tavistock. http:// dx.doi.org/10.4324/9780203359075 
Black, L.L., \& Stone, D. (2005). Expanding the definition of privilege: The concept of social privilege. Journal of Multicultural Counselling and Development, 33(4) 243-255.

Blackman, J.S. (2004). 101 Defences: How the mind shields itself. New York: BrummerRoutledge.

Booysen, L. (2007). Barriers to employment equity implementation and retention of blacks in management in South Africa. South African Journal of Labour Relations, 31(1), 47-71.

Branch, S., Ramsay, S., \& Barker, S. (2007). Managers in the firing line: Contributing factors to workplace bullying by staff - an interview study. Journal of Management and Organisation, 13(3), 264-282. http://dx.doi.org/10.5172/jmo.2007.13.3.264

Brewerton, P., \& Millward, L. (2004). Organisational research methods. A guide for students and researchers. London: Sage.

Brief, A.P., Umphress, E.E., Dietz, J., Burrows, J.W., Butz, R.M., \& Scholten, L. (2005) Community matters: Realistic group conflict theory and the impact of diversity. Academy of Management Journal, 48(5), 830-844. http://dx.doi.org/10.5465/ AMJ.2005.18803925

Brunner, L.D., Nutkevitch, A., \& Sher, M. (2006). Group relations conferences: Reviewing and exploring theory, design, role-taking and application. London: Karnac.

Brunning, H. (2006). The six domains of executive coaching: In H. Brunning (Ed.), Executive coaching: Systems-psychodynamic perspective (pp. 131-151). London: Executive coachi
Karnac Books.

Campbell, D. (2007). The socially constructed organisation. London: Karnac.

Cañas, K.A., \& Sondak, H. (2010). Opportunities and challenges of workplace Diversity. (2nd Edn.). New York: Prentice Hall.

Cavaleros, C., Van Vuuren, L., \& Visser, D. (2002). The effectiveness of a diversity awareness training programme. South African Journal of Industrial Psychology, 28(3), 50-61

Cheng, C. (1999). Marginalised masculinities and hegemonic masculinity: An introduction. Journal of Men's Studies, 7(3), 295-315. http://dx.doi.org/10.3149/ jms.0703.295

Cilliers, F. (2007). A systems psychodynamic exploration of diversity management. The experiences of the client and the consultant. South African Journal of Labour Relations, 31(2), 32-50.

Cilliers, F., \& Koortzen, P. (2000). The psychodynamic view on organisational behaviour. The Industrial-Organisational Psychologist, 38(2), 59-67.

Cilliers, F., \& May, M. (2002). South African Diversity Dynamics: Reporting on the 2000 Robben Island Diversity Experience: A group relations event. South African Journa of Labour Relations, 26(3), 42-68.

Cilliers, F., \& Smit, B. (2006). A systems psychodynamic interpretation of South African diversity dynamics: A comparative study. South African Journal of Labour Relations, 30(2), 5-18.

Cilliers, F., \& Stone, K. (2005). Employment equity practices in three South African Information Technology organisations: A systems psychodynamic perspective. South African Journal of Industrial Psychology, 31(2), 49-57.

Cilliers, F., \& Terblanche, L. (2010). The systems psychodynamic leadership coaching experiences of nursing managers. Health SA Gesondheid 15(1), Art \#457, 9 pages. http://dx.doi.org/10.4102/hsag.v15i1.45

Clarke, S., \& Hoggett, P. (2009). Researching beneath the surface. Psycho-social research methods in practice. London: Karnac.

Commission for Employment Equity Annual Report (2009). Department of Labour, Republic of South Africa.

Cox, T. (2004). Problems with research by organisational scholars on issues of race and ethnicity. The Journal of Applied Behavioural Science, 40(2), 124-145. http:// and ethnicity. The Journal of Applied Behovic
dx.doi.org/10.1177/0021886304263851

Cytrynbaum, S., \& Noumair, A. (2004). Group dynamics, organisational irrationality, and social complexity: Group relations reader 3. Jupiter: A.K. Rice.

Czander, W.M. (1993). Psychodynamics of work and organisations: Theory and application. New York: The Guilford Press.

Denzin, N.K., \& Lincoln, Y.S. (1994). Handbook of qualitative research. Thousand Oaks: Sage.

Devers, K.J. (1999). How will we know "good" qualitative research when we see it? Beginning the dialogue in health services research. HSR: Health Services Research, 34(5), Part II, 1153-1188.

Diamond, M. (2007). Organisational change and the analytic third: Locating and attending to unconscious organisational psychodynamics. Psychoanalysis, Culture and Society, 12(2), 142-164. http://dx.doi.org/10.1057/palgrave.pcs.2100116

Diamond, M., Allcorn, S., \& Stein, H. (2004). The surface of organisational boundaries: A view from psychoanalytic object relations theory. Human Relations, 57(1), 31 43. http://dx.doi.org/10.1177/0018726704042713

Dixon, J., \& Durrheim, K. (2003). Contact and the ecology of racial division: Some varieties of informal segregation. The British Journal of Social Psychology, 42(1),
1-23. http://dx.doi.org/10.1348/014466603763276090, PMid:12713753

Dobbin, F. (2009). Inventing equal opportunity. New York: Princeton University Press.

Dreachslin, J.L. (2007). The role of leadership in creating a diversity-sensitive organisation. Journal of Healthcare Management, 52(3), 151-155. PMid:17552352

Dyson, S., \& Brown, B. (2006). Social theory and applied health research. Berkshire: Open University Press.

Evans, J. (2007). Your psychology project: The essential guide. Los Angeles: Sage.
Feldner-Busztin, A. (2004). The diversity dividend. In T.N.A. Meyer \& I. Boninelli (Eds.) Conversation in leadership: South African perspectives (pp. 133-146). Randburg: Knowledge Resources.

Field, M.J., \& Jette, A.M. (2007). The future of disability in America. Washington DC: The National Academies Press.

Fleras, A. (2009). The politics of multiculturalism: Multicultural governance in comparative perspective. New York: Palgrave.

Foley, S., Linnehan, F., Greenhaus, J.H., \& Weer, C.H. (2006). The impact of gender similarity, racial similarity and work culture on family-supportive supervision. Group and Organisation Management, 31(4), 420-442. http://dx.doi. org/10.1177/1059601106286884

Foster, A., Dickinson, A., Bishop, B., \& Klein, J. (2006). Difference: An avoided topic in practice. London: Karnac.

Fraser-Moleketi, G. (2001). Tackling diversity. In UNDESA-IISA (Eds.) Managing diversity in the civil service (pp. 31-40). Amsterdam: IOS Press.

French, R., \& Vince, R. (1999). Learning, managing and organising: The continuing contribution of group relations to management and organisations. In R. French \& R. Vince (Eds.) Group relations, management and organisation (pp. 1-22). Oxford: Oxford University Press.

Freud, S. (1948). Inhibitions, symptoms and anxiety. (J. Strachey, Trans). London: The Hogarth Press.

Golafshani, N. (2003). Understanding reliability and validity in qualitative research The Qualitative Report, 8(4), 597-607.

Hannum, K., McFeeters, B.B., \& Booysen, L. (2010). Leading Across Differences Facilitator's Guide Set. New York: Jossey Bass Wiley

Healy, M., \& Perry, C. (2000). Comprehensive criteria to judge validity and reliability of qualitative research within the realism paradigm. Qualitative Market Research, 3(3), 118-126. http://dx.doi.org/10.1108/13522750010333861

Heames, J., \& Harvey, M. (2006). Workplace bullying: A cross-level assessment. Management Decision, 44(9), 1214-1222. http://dx.doi. org/10.1108/00251740610707695

Hebl, M., Madera, J.M., \& King, E. (2008). Exclusion, avoidance and social distancing. In K.M. Thomas (Ed.) Diversity resistance in organisations (pp. 127-150). New York: Lawrence Erlbaum Associates.

Henning, E. (2004). Finding your way in qualitative research. Pretoria: Van Schaik.

Hilliard, G. (2001/2002). Beyond the confines of compliance and virtue: Honing asset of global ethics for South Africa and the United States of America. Public Administration Quarterly, 25(3/4), 436-462.

Hopkins, B. (2009). Cultural differences and improving performance: How values and beliefs influence Organisational performance. London: Gower.

Huffington, C., Armstrong, A., Halton, W., Hoyle, L., \& Pooley, J. (2004). Working below the surface. The emotional life of contemporary organisations. London: Karnac.

Human, L. (2005). Diversity management for business success. Pretoria: Van Schaik.

Hyter, M.C., \& Turnock, J.L. (2005). The power of inclusion: Unlock the potential and productivity of your workforce. Mississauga: John Wiley \& Sons.

Jung, C. (2000). Then I was black: South African political identities in transition. New Haven: Yale University Press.

Kashlak, R., Phatak, A.V., \& Bhagat, R.S. (2009). International management: Managing in a diverse and dynamic global environment. New York: McGraw Hill.

Kets de Vries, M.F.R., \& Engellau, E. (2004). Organisational dynamics in action. In T.N.A. Meyer \& I. Boninelli (Eds.) Conversations in leadership: South African perspectives (pp. 18-38). Randburg: Knowledge Resources.

Kets de Vries, M.F.R. (2004). Organisations on the couch: A clinical perspective on organisational dynamics. European Management Journal, 22(2), 183-200. http://dx.doi.org/10.1016/j.emj.2004.01.008

Kets de Vries, M.R.F., \& Korotov, K. (2007). The clinical paradigm: A primer for personal change. In M.R.F. Kets de Vries, K. Korotov \& E. Florent-Treacy (Eds.), Coach and couch: The psychology of making better leaders (pp. 3-14). Hampshire: Palgrave Macmillan.

Kilburg, R. (2004). When shadows fall: Using psychodynamic approaches in executive coaching. Consulting Psychology Journal: Practice and Research, 56(4), 246-268. http://dx.doi.org/10.1037/1065-9293.56.4.246

Kilburg, R.R., \& Diedrich, R.C. (2007). The wisdom of coaching: Essential papers in consulting psychology for a world of change. Washington DC: APA. http://dx.doi. org/10.1037/11570-000

Kirton, G., \& Greene, A. (2010). The dynamics of managing diversity: A critical approach. New York: Butterworth-Heinemann.

Klein, M. (1997). Envy and gratitude and other works 1946-1963. London: Vintage.

Klenke, K. (2008). Qualitative research in the study of leadership. Bingley: Emerald Group Publishing.

Korostelina, K.V. (2007). Social identity and conflict: Structures, dynamics and implications. New York: Palgrave Macmillan.

Laubscher, C. (2001). Managing diversity. People Dynamics, 19(8), 16-18.

Le Roux, J.R.J. (2003). Corporate reputation in the information technology industry: A South African case study. Masters Dissertation. University of Pretoria, Pretoria.

Lee, G. (2010). The psychodynamic approach to coaching. In E. Cox, T. Bachkirova \& D. Clutterbuck (Eds.), The complete handbook of coaching (pp. 23-36). London: SAGE.

Livermore, D.A. (2009). Leading with cultural intelligence: The new secret to success. New York: Amacom. 
Lowman, R.L. (2002). The handbook of organisational consulting psychology. San Francisco: Jossey-Bass.

Lutgen-Sandrik, T.S.J., \& Alberts, J.K. (2006). Nightmares, demons and slaves: Exploring the painful metaphors of workplace bullying. Management Communication Quarterly, 20(2), 148-186. http://dx.doi.org/10.1177/0893318906291980

Lyth, I.M. (1989). The dynamics of the social: Selected essays, Volume 2. London: Free Association Books

Mbola, B. (2008). Chinese South Africans qualify for BEE. Retrieved April 20 2009, from http//www.southafrica.info/business/trends/empowerment/ beechinese-180608.htm

McCormick, D.W., \& White, J. (2000). Using one's self as instrument for organisational diagnosis. Organisational Development Journal, 18(3), 49-62.

McRae, M.B., \& Short, E.L. (2010). Racial and cultural dynamics in group and organisational life. Crossing boundaries. Los Angeles: Sage.

Meyer, T.N.A., \& Boninelli, I. (2004). Conversation in leadership: South African perspectives. Randburg: Knowledge Resources.

Motsoaledi, L.S.P. (2009). Executive coaching in diversity from a systems psychodynamic perspective. Unpublished Doctoral dissertation. University of South Africa, Pretoria.

Mujtaba, B.G. (2009). Workforce diversity management: Challenges, competencies and strategies. London: Academy.

Myers, M. (2000). Qualitative research and the generalisability question: Standing firm with proteus. The Qualitative Report, 4, (3/4).

Newton, J., Long, S., \& Siever, B. (2006). Coaching in depth: The organisational role analysis method. London: Karnac Books.

Peltier, B. (2001). The psychology of executive coaching: Theory and application. New York: Brunner-Routledge.

Pretorius, M. (2003). An exploration of South African diversity dynamics. Unpublished M.A. Dissertation, University of South Africa, Pretoria.

Rowley, J. (2004). Researching people and organisations. Library Management, 25(4/5), 208-214. http://dx.doi.org/10.1108/01435120410533792

Schaepkens, L. (2010). Workplace diversity management. London: Muller Aktiengesellschaft.

Schiffrin, D., Tannen, D., \& Hamilton, H.E. (2001). The handbook of discourse analysis. Oxford: Blackwell Publishers.

Sidanius, J., \& Pratto, F. (1999). Social dominance: An intergroup theory of social hierarchy and oppression. Cambridge: Cambridge University Press.

Sievers, B. (2009). Psychoanalytic studies of organizations. Contributions from the International Society for the Psychoanalytical Study of Organizations (ISPSO) London: Karnac.
Simpson, A. (2008). Language and national identity in Africa. New York: Oxford University Press.

Smit, B., \& Cilliers, F. (2006). Understanding implicit texts in focus groups from systems psychodynamic perspective. The Qualitative Report, 11(2), 302-316.

Sonn, C.C., \& Fisher, A.T. (2003). Identity and oppression: Differential responses to an in-between status. American Journal of Community Psychology, 31(1-2), 117128. http://dx.doi.org/10.1023/A:1023030805485, PMid:12741694

South African Department of Labour. (2004). Retrieved March 22, 2010, from http:// www.labour.gov.za

Stapley, L.F. (2006). Individuals, groups and organisations beneath the surface: An introduction. London: Karnac.

Sue, D.W. (2006). Multicultural social work practice. Hoboken: John Wiley \& Sons.

Syed, J., \& Murray, P. (2008). A cultural feminist approach towards managing diversity in top management teams. Equal Opportunities International, 27(5), 413-432. $\mathrm{http}: / / \mathrm{dx}$.doi.org/10.1108/02610150810882288

Tajfel, H. (1981). Human groups and social categories: Studies in social psychology. Cambridge: Cambridge University Press.

Terre Blanche, M., Durrheim, K., \& Painter, D. (2006). Research in practice. Applied methods for the social sciences. Cape Town: UCT Press.

Thomas, K.M. (2005). Diversity dynamics in the workplace. Belmont: Thomson/ Wadsworth.

Thomas, A. (2002). Employment equity in South Africa: Lessons from the global school. International Journal of Manpower, 23(3), 237-255. http://dx.dol. org/10.1108/01437720210432211

Townley, B. (2008). Reasons' neglect: Rationality and organising. New York: Oxford University Press.

Turquet, P.M. (1974). Leadership: the individual and the group. In G.S. Gibbard, J.J. Hartman \& R. Mann (Eds.), Analysis of groups. San Francisco: Jossey-Bass.

Van Jaarsveld, F., \& Van Eck, S. (2002). Principles of labour law. Durban: Butterworths.

Van Manen, M. (1990). Researching lived experience. Toronto: State University of New York.

White, K. (2006). Unmasking race, culture, and attachment in the psychoanalytic space. What do we see? What do we think? What do we feel? London: Karnac.

Winnicott, D.W. (1965). The maturational processes and the facilitating environment: Studies in the theory of emotional development. New York: International Universities Press Inc.

Yin, R.K. (2003). Applications of case study research. Thousand Oaks: SAGE. 